\title{
自記オージオグラム $\mathrm{V}$ 型の検討
}

弘前大学医学部耳鼻咽喉科学教室

坂本伸一郎, 斉藤 久樹, 古島真理子

\section{I はじめに}

1961年, Jerger and Herer ${ }^{2)}$ は Békésy audiogram において, 持続音域値より断続音域值が上昇する型の あることを報告し，以前 Jerger ${ }^{1)}$ (1960年)にようて Békésy audiogram をIV型に分類されたほかに, 本現 象を追加し，V型とした。その後，本現象に関する文 献は数多くみられるが, non-organic hearing loss の 例にV型が出現するといら観点から検討が加えられて きている。今回著者らは，最近 3 年間に当教室を訪 れ，Békésy audiometry を施行したもののうちでV型 を示した症例を選び出し, non-organic hearing loss の 鑑別診断上の立場より検討を加え，若干の知見を得た のでここに報告する。

\section{II 検 討 対 象}

昭和 45 年から 47 年の 3 年間に, 固定周波数自記オ一
ジオメトリーを施行したもの，452 例中，持続音刺激 域值と断続音刺激域值レベルの比較 (C-I gap) で, 断 続音域值の方が $5 \mathrm{~dB}$ 以上上后している11例について 検討を加えた。

性別は男 9 人，女 2 人

年令は 10 才以下 4 人， 20 代 4 人，40代 2 人，50代 1 人である。

\section{III 検查方法, 条件}

検查周波数は主に $1 \mathrm{kHz} ， 4 \mathrm{kHz}$ で行われた。2 症例については $1 \mathrm{kHz}$ のかわりに $500 \mathrm{~Hz}$ で行われ た。

\section{自記オージオメトリーの検查条件}

減衰速度 $2 \mathrm{~dB} / \mathrm{sec}$, 紙送り速度 $24 \mathrm{~mm} / \mathrm{min}$, 減衰 テップ0.02dB で, 断続音刺激の条件は, 周期 $500 \mathrm{msec}$, duty cycle $50 \%$ ，立ち上り立ち下り時間 $25 \mathrm{msec}$ とし た。，固定周波数自記オージオメトリーにて施行，記録

\begin{tabular}{|c|c|c|c|c|c|c|c|c|c|c|c|c|c|c|c|}
\hline & \multirow{3}{*}{$\begin{array}{l}\text { 年 } \\
\text { 令 }\end{array}$} & \multirow{3}{*}{ 性 } & \multirow{3}{*}{ 診 } & \multicolumn{3}{|c|}{ 右 $1 \mathrm{kHz}$} & \multicolumn{3}{|c|}{ 右 $4 \mathrm{kHz}$} & \multicolumn{3}{|c|}{ 左 $1 \mathrm{kHz}$} & \multicolumn{3}{|c|}{ 左 $4 \mathrm{kHz}$} \\
\hline & & & & 振 & 幅 & C I & 振 & 幅 & C I & 振 & 幅 & C I & 振 & 幅 & C I \\
\hline & & & & $\mathrm{C}$ & I & ，差 & $\mathrm{C}$ & I & 差 & $\mathrm{C}$ & I & 差 & $\mathrm{C}$ & I & 差 \\
\hline 1 & 23 & $\hat{o}$ & Reflex Epilepsy & 13 & 8 & -5 & 8 & 5 & -8 & 9 & 6 & -5 & 4 & 8 & 2 \\
\hline 2 & 57 & $\hat{o}$ & 兩側感音性難聴 & 6 & 5 & -6 & 7 & 8 & 0 & 5 & 6 & 3 & 5 & 6 & 4 \\
\hline 3 & .9 & $\delta$ & 兩側感音性難聴 & 5 & 6 & 15 & 4 & 3 & $5^{-}$ & 3 & 5 & -6 & 3 & 3 & 1 \\
\hline 4 & 27 & 웅 & 両側感音性難聴 & 7 & 6 & -7 & 2 & 4 & 6 & 5 & 6 & 0 & 4 & 6 & 8 \\
\hline 5 & 21 & $\hat{o}$ & 右突発性難聴疑 & 6 & 6 & 3 & 3 & 5 & 9 & 8 & 8 & -5 & 5 & 5 & 8 \\
\hline 6 & 9 & $q$ & 両側感音性難聴 & 8 & 8 & 0 & 4 & 8 & -3 & 7 & 7 & -3 & 5 & 10 & -8 \\
\hline 7 & 9 & $\hat{o}$ & 心因性難聴疑 & 5 & 7 & 3 & 4 & 8 & -3 & 6 & 6 & -5 & 3 & 8 & -13 \\
\hline 8 & 42 & $\hat{o}$ & 両側感音性難聴 & 8 & 8 & -5 & 8 & 7 & 5 & 4 & 4 & 4 & 3 & 5 & 3 \\
\hline 9 & 9 & $\hat{o}$ & 右感音性難聴 & 4 & 5 & -10 & 4 & 5 & -4 & 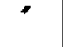 & & & & & \\
\hline 10 & 28 & $\hat{o}$ & $\mathrm{~S} \quad \mathrm{M}$ 難 聴 & 6 & 5 & 8 & 5 & 5 & 4 & 12 & 7 & -5 & 5. & 5 & 5 \\
\hline 11 & 49 & $q$ & 両側感音性難聴 & 3 & .5 & 13 & 2 & 5 & 20 & 8 & 6 & -5 & 3 & 5 & 4 \\
\hline
\end{tabular}

検查順序 症例 $1 \sim 7^{\circ}$ 右 $1 \mathrm{kHz}$ 上り 症例 8,9 右 $4 \mathrm{kHz}$ より 症例10,11 左 $1 \mathrm{kHz}$ より
症例 $4,50.5 \mathrm{kHz}$ 施行

$\mathrm{C}$; 持続音刺激

I ; 断続音刺激 
時間は持続音，断続音刺激とも，それぞれ 3 分以上亡 した。

\section{IV 結果}

衰 1 に示すごとく，1kHz（または $500 \mathrm{~Hz}$ ）および $4 \mathrm{kHz}$ ともに断続音刺激域值が $5 \mathrm{~dB}$ 以上上昇している 例は 2 例 2 耳（症例 $1 ， 7$ ) のみで残り9例恃左右い ずれかの $1 \mathrm{kHz}$ むしくは，4kHz の一方のみ浪めら れた。衰 1 で C.I gap は，持続音域值から断続音域 值を引いたもので，マイナスは，断続音域值が持続音 域值より上昇していることを示している。

臨床診断の面からこの11例をみると，症例 1 と症例 7 を除いた 9 例はいずれる病歴，各種聴力検查などよ り，器質的聴覚障害が考えられた症例であった。症例 1は精神科にて reflex epilepsy の診断を受けてお り，純音聴力検查では域值の上昇は認められなかっ た。症例 7 は心因性難㯖が疑われている症例で, 現在 む経過観察恶続けている例で, 詳細に関しては後述し ます。

次に自記オージオメトリーの施行順序といら点よ り，本現象の出現の検討を行った。表 1 において，症 例 1 から 7 までは右 $1 \mathrm{kHz}$ から検査を開始して拈り, 症例 8,9 桜右 $4 \mathrm{kHz}$ 分ら, 症例10, 11 は左 $1 \mathrm{kHz}$ 加 ら行っているが，最初に行った周波数のみに本現象が 出現したものが 4 例（症例 $2 ， 4 ， 10 ， 11 ）$ あった。こ れらの症例はいずれむ器質的聴覚障害莸有する例であ った。

自記オージオメトリーを 2 回以上施行した例は 3 例 あり，第 1 例目は症例 9 で, 右耳のみ検査されてお り, 初回に $1 \mathrm{kHz}, 4 \mathrm{kHz}$ 共断続音域值の上昇があっ たが，図１に示すごとく 4 カ月後の再検時には, 純音 聴力検査で特に変動は認められなかったが, 自記オ一

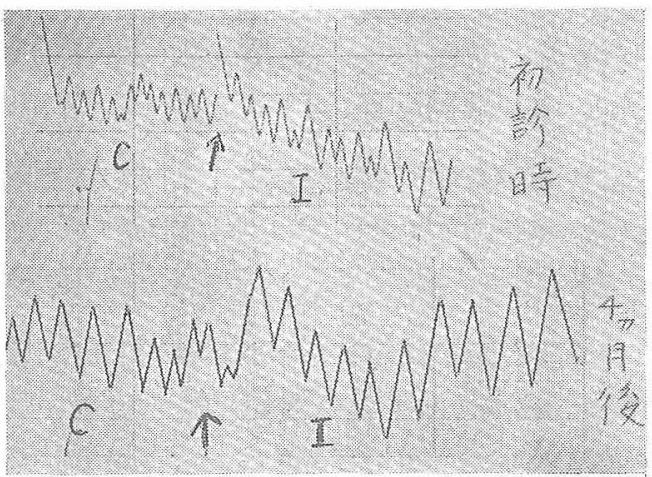

図1 右 $1 \mathrm{KHz}$ (症例 9 )
ジオグラム $4 \mathrm{kHz}$ では, C-I gap の消失と, 持続音, 断続音振幅の增大が認められた。 $1 \mathrm{kHz}$ では持続音, 断続音振幅の増大があったが，C-I gap は変化しなか った。

第 2 例目は症例11で, 2 力月後の再検時には, 純音 聴力検査で，やはり著明な域值変動はなかったが，自 記オージオグラムでは図 2 のごとく，左 $1 \mathrm{kHz} て ゙ \mathrm{C}-I$ gap 注逆䎐し，持続音域值の方が上昇していた。他側 および他周波数では著変は認めなかった。

第 3 例目 様左 $4 \mathrm{kHz}$ 之，新たに右 $4 \mathrm{kHz}$ で， $5 \mathrm{~dB}$ 以上断続音域 值が上昇していた。この症例は，初回，再検時共に， 左在 $1 \mathrm{kHz} ， 4 \mathrm{kHz} 4$ つの検查のう ち2 つに断続音域 值の上昇を示した例で，以後現在に至る約 2 年半の経 過観察結果について述べる。

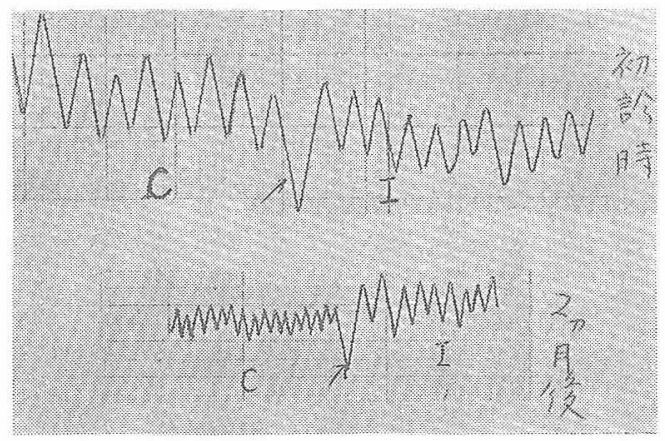

圆 2 左 $1 \mathrm{KHz}$ (症例11)

\section{症例}

9 才11力月 男

初診：昭和46年 9 月 13 日

家族歴：特記事項なし

既往歴：銝子分婏であったが特に異常はなかった。 約 3 年前㴔性中耳炎。

現病歴：昭和46年春頃より，先生の言葉が良く聞き とれなくなった。特に語尾が聞こ光ないことが多かっ た。また，時に聞こえが良くなったり恶くなったりす ることがあった。耳鳴，眩愠梳訴えていない。母親は 46年より患者がテレビの音を大きくして閎くので，変 だと思っていた。7月夏休み前と，8月 2 学期が始じ まってからの 2 回，本人から授業がよく聞きとれない といわれ，また隣りの席の友人の母親上り，患者の聴 カについての忠告があったため, 精査を希望し来院し た。

難聴自覚前後の生活環境 
3 年前画親が離婚，小学校 2 年生の洔，母親と， 1 才下の妹と共に，他県より青森県に転入，母親は銀行 の掃除婦として働いている。難㯖自覚時，学校では背 が大きいため，席が一番後であった。しかし，前の方 飞行きたいと思わなかったし，かえって背が大きいの に前の方に行くのは気がひけたくらいであった。聞こ えが悪くなっても席が前になったので，特に不自由は なかったし，不安も㐫りなかった。学校へ行くのは 好きである。

性格は, 無曰, 内気で, 質問に対しては, 主に母親 が応答。動物が好きで, 外来堂訪れる他の子供達に, 自分の飼っている虫などを喜こんであげていた。学業 成績も良い方である。

現症：

鼓膜雨側軽度陥凹

鼻咽喉頭は異常を認めない。

検査結果 :

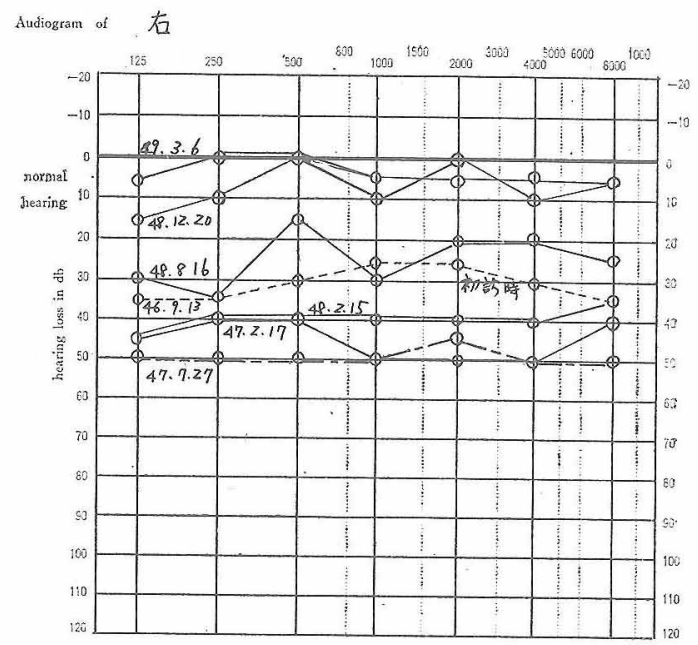

図4 聴力損失
耳のレ線写真に異常它認めない。

純音聴力検查では图 3 のごとく, 兩側水平型の感音 Audiogram of

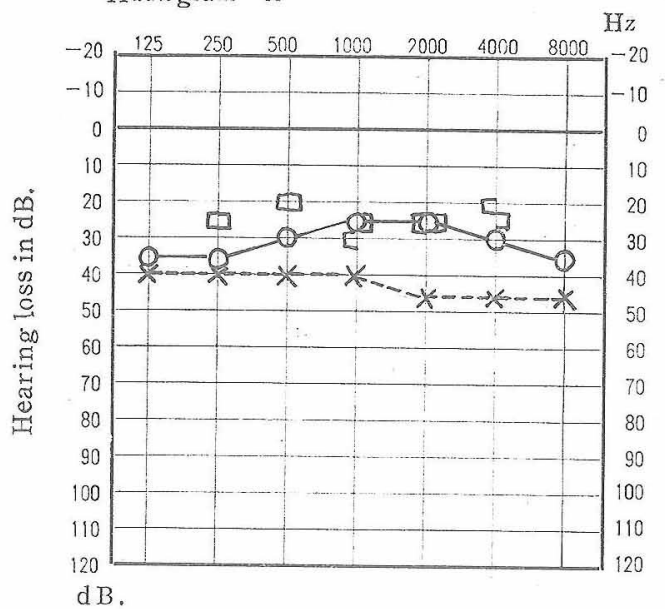

図 3 初崄時聴力（症例 7)

Audiogrean of 左

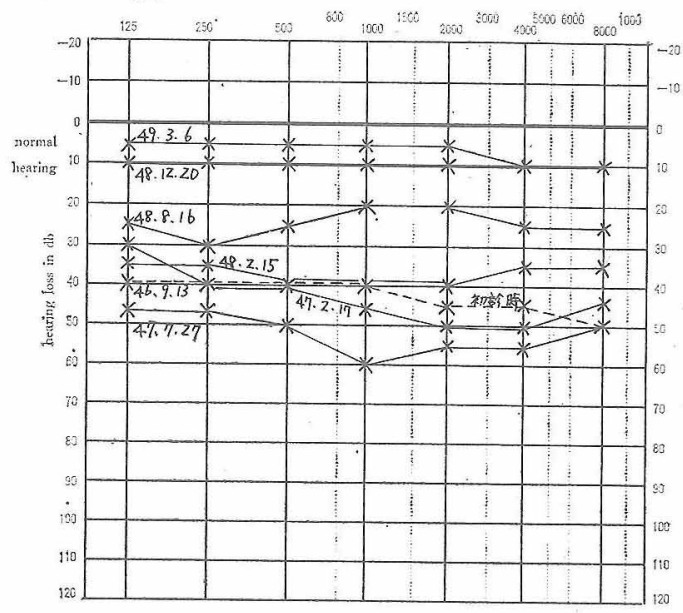

の推移 (症例 7)

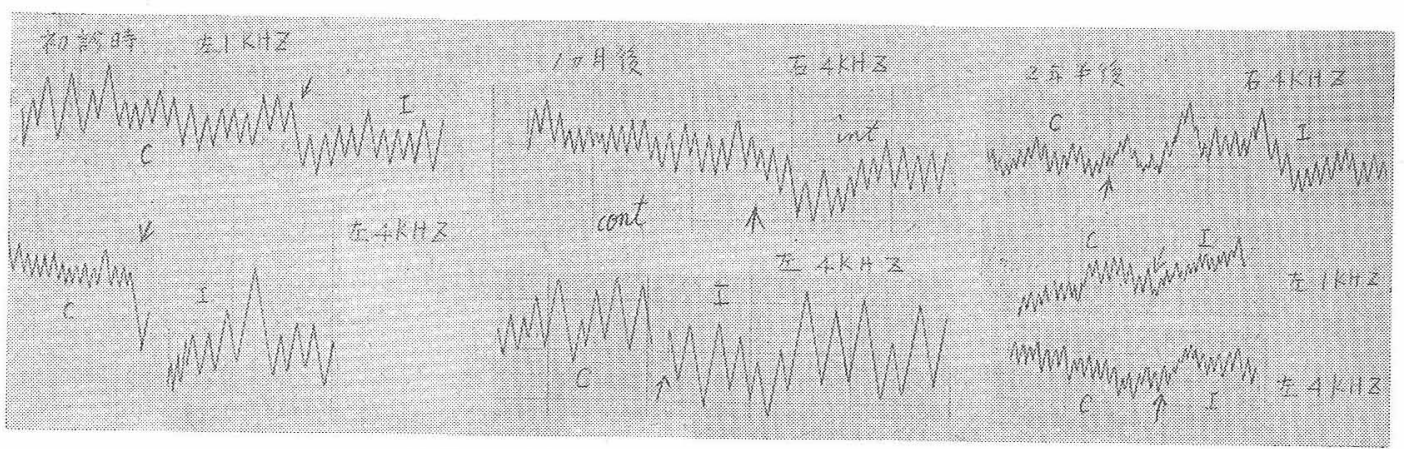

図 5 自記オージオグラムの推移（症例 7） 
性難聴を示した。

SISI-score 汇両側 $1 \mathrm{kHz} ， 4 \mathrm{kHz}$ と 陰性（increment $4 \mathrm{~dB}$ Kても)

自記オージオメトリーでは図 5 に示すごとく右 1 $\mathrm{kHz}$ で $5 \mathrm{~dB}$ ，右 $4 \mathrm{kHz}$ で $13 \mathrm{~dB}$ 断続音域值の方が上昇

していた。

ワッセルマン反応はマイナスであった。

経過：

純音聴力検査は，初診時より昭和 48 年 2 月をでの約 1 年半の間は 1 力月に 1 回行われた。経過注図 4 亿示 すごとく，やや悪化した時期があったが，お扔むね不 変であった。その間補聴器を購入したがあまり使用し たがらず，授業の時，時々使うことがある程度であっ た。

昭和 48 年 8 月より徐々に改善を示し始じめ, 48 年 12 月，49年 3 月の検查では，正常範囲にまで改善した。 自記オージオメトリーは初診時も含め, 3 回行わ れ, 図 5 のように初診時には左右 $4 \mathrm{kHz}$ で, 1 力月後 の再検時には左 $1 \mathrm{kHz}, 4 \mathrm{kHz}$ で断続音域值が持続音 域値より $5 \mathrm{~dB}$ 以上，上昇していた。純音聴力検査で 正常值を示した昭和 49 年 3 月（初診より約 2 年半後） の検査では, 各周波数とも, 振幅の縮少があったが, いずれも断続音域值の上昇は認められなくなり，気 導, 骨導聴力域値とも正常値を示した。

\section{IV 考按}

Jerger (1960) ${ }^{1)}$ 分類が発表されて以来, 持続音刺 激および断続音刺激の振幅と域值の比較といら観点よ り，自記オージオメトリーは種々の難聴の鑑別診断に 利用されている。

1961年 Jerger and Herer ${ }^{2}$ が, 連続周波数自記才 ージオグラムで，断続音域值が持続音域值より上昇す る曲線のあることを報告し,新たにV型とし，本現象が いわゆる non-organic hearing loss の症例に出現する ことを報告して以来, その後この点について Resnick \& Burke $(1962)^{3)}$, Peterson $(1963)^{4)}$, Stein $(1963)^{5)}$, Juers $(1966)^{6)}$ などの追加報告が認められ，マずれも Jerger らの考えを支持し, non-organic hearing loss の 症例に高率に出現していることを発表している。

Resnick and Burke ${ }^{3)}$ ほ，3例の両耳に断続音域値 より持続音域値の良い例を挙げ，そのほかの種々の検 查成績より non-organic hearing loss 例にこのような 例が認められたことを報告している。

Peterson ${ }^{4}$ は はon-organic hearing loss を有する 4
症例（いずれむ小奣）について全例がV型を示してい ることを述へ，また Stein $^{5)}$ は 100 例の軍人について 自記オージオメトリーを施行し，そのうち 30 例の functional heariag loss 症例中17例 $(57 \%)$ にV型が 認められ，さらに残り13例中 9 例は Jerger の記载し た 5 型のらちいずれにも当てはまらない型のものであ。 ったと報告している。

Juers $^{6)}$ は純音域值より語音聴取域值が 良好な例で 自記オージオグラム゙上ர்型を示す例は non-organic hearing loss の可能性が高いことを強調している。一方

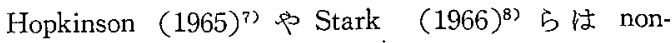
organic hearing loss に特有に出現する現象であるとい ら考えには批判的な立場をとり, 正常, 伝音性難㯖, 感音性難聴例に扔いても出現する場合があることを報 告している。すなうち Hopkinson? ${ }^{72}$ は伝音性難聴を有 する52例中25例がV型を示したことより；自記オージ オメトリーの検查条件, 被検者の慣れなどによって本 現象が出現する可能性を示唆しており，V型は nonorganichearing loss の指標とはなり得ないことを述べ ている。 Stark $^{8)}$ を，61例の正常者および52例の感音 性難聴を有する児童について自記オージオメトリーを 施行し, 正常例で $4.9 \%$ ，感音性難聴例で8.6\%にV型 を認めている。

こ杂らの報告は $\mathrm{Stark}^{8)}$ を除いてすべて連続周波数 自記オージオメトリーによる観察結果であるが，今回 の著者らの成績は固定周波数自記オージオメトリーに よるもので，検查周波数は $1 \mathrm{KHz}$ と $4 \mathrm{KHz}$ によるもの が殆んどを占ている。著者らの成績では 452 例の自記 オージオメトリー施行例中11例 (2.4\%) 飞断続音刺激 時の域值が持続音刺激時のそれより上昇していた。こ の頿度は多くの先人達の報告に比べて少ない。これは 検査対象および検查条件による相違であろらと思われ る。

またいわゆるり型を示した11例中，自記オージオメ トリーで最初に施行した周波数のみにV型が出現した 例が 4 例もあり，この点，本現象が Hopkinson?? のい う untrained subject $に V$ 型の出現する場合があるこ とを示唆している。さらに，2 回以上施行した例 3 例 中, 2 例に再検時 $\mathrm{V}$ 型が消失している点からみて, 本 現象には被検者の自記法に対する慣れを含めた種々の 要因が関与していることを示している。しかし一方で は，再三の検査にて絶えずV型を示す例があり，この 症例怡臨床的長期観察より心因性難聴と思われた例で あった点より，V型と心因性難聴との間に何等かの 
関連性を有する例が確かに存在すると思われる。

\section{VI ま゙ め}

1) 固定周波数自記オージオメトリー施行例中，2.4 \%に Jerger 分類のV型を示したが, その大部分は器 質的聴覚障害例であった。

2）V型を示した11例中 1 例のみが，心因性難聴と思 われる例であった。この例は両耳共, 再度の検查で同 一のV型の所見を示した。

3）一つの周波数のみに出現した $V$ 型や, 再検查で消 失する例は，心因性難聴とは無関俰なものであろうと 考えた。この場合、V型の出現は被検者の検查に対す る慣れなどを含めた要因によると思われた。

\section{Some Observation on Type $\mathrm{V}$ of Fixed- Frequency Békésy Audiogram}

Shin-ichiro Sakamoto, M.D., Hisaki Saito, M.D., \& Mariko Kozima, M.D.

Department of 'Oto-laryngology, School of Medicine, Hirosaki University, Hirosaki.

The fixed-frequency threshold tracings at $1,000 \mathrm{~Hz}$ and $4,000 \mathrm{~Hz}$ for periodically interrupted and continuous tones were obtained on 452 cases with various types of auditory disorders.

Eleven cases among them showed type $\mathrm{V}$ audiogram in that the threshold for periodically interrupted tone is tracked at lower levels than thethreshold for continuous tone on one or more frequency tracings.'

One case was suspected of non-organic hearing loss, and another case was diagnosed of reflex epilepsy' with normal threshold.

Other 9 cases was diagnsoed of sensori-neural hearing loss and they showed type $\mathrm{V}$ at only one frequency threshold tracing.

Authors considered that type $\mathrm{V}$ obtained at only one frequency threshold tracing did not indicate nonorganic hearing loss.

\section{文献}

1) Jerger, J.: Békésy audiometry in analysis of auditory disorders. J. Speech Hearing Res., 3 ; 275, 1960.

2) Jerger, J. and Herer, G.: Unexpected dividend in Békésy audiometry. J. Speech Hearing Dis., $26 ; 390,1961$.

3 ) Resnick, D.M. and Burke, K.S.: Békésy audiometry in non-organic hearing problems. Arch. Otolaryng., $76 ; 50,1962$.

4) Peterson, J,L.: Nonorganic hearing loss in children and Békésy audiometry. J. Speech Hearing Dis., 28 ; 153, 1963.

5 ) Stein, L. : Some observation on type V Békésy tracings J. Speech Hearing Res., 6 ; 339, 1963.

$6)$ Juers, A.L.: Non-organic hearing problems. Laryngoscope, $76 ; 1714,1966$.

7) Hopkinson, N.T.: Type V Békésy audiograms: specification and clinical utility. J. Speech Hearing Dis., $30 ; 243,1965$.

8) Stark, E.W.: Jerger types in fixed-frequency Békésy audiometry with normal and hypacusic children. J Aud. Res., 6 ; 135, 1966.

（受付 49.3.28） 